\title{
ArcheoSciences
}

Revue d'archéométrie

\section{An Interim Investigation of the Potential of Vibrational Spectroscopy for the Dating of Cultural Objects in Ivory}

Une première investigation du potentiel de la spectroscopie vibrationnelle pour la datation d'objets historiques en ivoire

\section{Sonia O'Connor, Howell G. M. Edwards and Esam Ali}

\section{OpenEdition}

\section{Journals}

\section{Electronic version}

URL: https://journals.openedition.org/archeosciences/3091

DOI: 10.4000/archeosciences.3091

ISBN: 978-2-7535-1849-0

ISSN: 2104-3728

\section{Publisher}

Presses universitaires de Rennes

\section{Printed version}

Date of publication: 30 April 2011

Number of pages: 159-165

ISBN: 978-2-7535-1847-6

ISSN: 1960-1360

Electronic reference

Sonia O'Connor, Howell G. M. Edwards and Esam Ali , "An Interim Investigation of the Potential of Vibrational Spectroscopy for the Dating of Cultural Objects in Ivory", ArcheoSciences [Online], 35 | 2011, Online since 30 April 2013, connection on 05 March 2022. URL: http://journals.openedition.org/ archeosciences/3091 ; DOI: https://doi.org/10.4000/archeosciences.3091 


\title{
An Interim Investigation of the Potential of Vibrational Spectroscopy for the Dating of Cultural Objects in Ivory
}

\author{
Une première investigation du potentiel de la spectroscopie vibrationnelle \\ pour la datation d'objets historiques en ivoire
}

\author{
Sonia O’Connor*, Howell G. M. Edwards** and Esam Ali ${ }^{* *}$
}

\begin{abstract}
Radiocarbon dating of ivory requires destructive sampling on a scale not always compatible with the requirements of the preservation and curation of cultural objects. The development of a minimally-destructive dating technique is urgently needed. Raman spectroscopy can detect the changes in the organic and inorganic molecular components of ivory that occur with time. It has been suggested that these vibrational spectroscopic changes could be used to assess the relative date of mammoth ivories, assuming that the state of preservation of the ivory is directly related to its age. This paper tests this assumption with specimens of mammoth ivory of known date and burial environment and concludes that the vibrational spectra of ivory cannot in general be used to deduce the age of the specimen.
\end{abstract}

Resumé : La datation au radiocarbone de livoire exige un échantillonnage destructif d'une taille qui n'est pas toujours compatible avec les exigences de la préservation et la conservation des objets du patrimoine culturel. Le développement d'une technique de datation la moins destructive possible est devenue une nécessité. La spectroscopie Raman peut détecter les changements dans les composants moléculaires organiques et inorganiques d'ivoire, qui se produisent avec le temps. Il a été suggéré que ces changements pourraient servir à estimer une datation relative des ivoires de mammouths, en supposant que l'état de conservation de l'ivoire est directement lié à son âge. Cet article teste cette hypothèse avec des spécimens d'ivoire de mammouth d'àge connu qui ont subi un enfouissement dans des conditions également connues. Cette étude montre que les spectres vibrationnels d'ivoire ne peuvent pas, en général, être utilisés pour en déduire l'àge d'un spécimen d'ivoire.

Keywords: FTIR spectroscopy, dating, ivory, mammoth, Raman spectroscopy.

Mots clé : spectroscopie FTIR, datation, ivoire, mammouth, spectroscopie Raman .

\section{INTRODUCTION}

The dating of bone and ivory objects is fundamental to their authentication, to the development of archaeological and historical typographies, and to the detection of the trafficking of CITES protected materials. The age of the raw materials of these objects, although not necessarily the date at which they were worked, can be gained through AMS ${ }^{14} \mathrm{C}$ dating. However, this technique requires a sample to be removed from the object; the sample size being determined by the level of survival of the collagen component of these organic/mineral composite materials. In many cases, destructive sampling on the scale required is incompatible with the requirements of the preservation and curation of the

* Archaeological Sciences, School of Applied Sciences, University of Bradford, BD7 1DP, UK.

** Chemical and Forensic Sciences, School of Applied Sciences, University of Bradford, BD7 1DP, UK. 
object. The development of a minimally-destructive dating technique has therefore been sought with some urgency.

Banerjee et al. (2008), in investigating the relative state of the organic and inorganic components of permafrost-preserved mammoth ivory, demonstrated measurable differences in the crystalline state of the material in three different commercial qualities (i.e. unweathered to extremely weathered) used by modern ivory carvers. XRD, Rietveld method, and FTIR spectroscopy both detected an increase in the size, particularly the length, of the bioapatite (carbonated hydroxyapatite) crystals with increased weathering. In addition, FTIR spectroscopy detected degradation of the collagen component and changes in chemical composition of the bioapatite in direct correlation with the increase in size of the crystallite. Assuming that the least weathered samples were the youngest and that weathering increased with increasing age, this led Banerjee et al. to conclude that the changes observed in the spectra could be used to assess the relative date of the mammoth ivories. As a direct result of that publication, the possibility that FTIR spectroscopy could be used to date ivories quickly gained currency in the museum world, as it seemed to offer a less destructive alternative to radiocarbon dating.

Directly correlating changes in the organic and inorganic components of osseous materials with age is a simplistic approach that does not take into account the potential effect of the burial environment. A dating technique based on preservation parameters would certainly not be capable of producing absolute dates as the rate of these changes are largely dependant on variables such as the thermal history of the object, the degree of sub-aerial weathering undergone and the nature of the burial environment. It is well understood that different burial conditions affect the rate and trajectory of the bone diagenesis (Smith et al., 2007; Nielsen-Marsh et al., 2007). Edwards et al. (2005; 2006) clearly demonstrate that the relationship between age and state of preservation of archaeological ivory from different sites is not straight forward. As a technique for relative dating it would also, therefore, be unlikely to produce meaningful results for ivories with different biographies i.e. fossil ivory compared with sub-fossil ivory or ivory preserved in desiccated environments with those from waterlogged deposits. However, Bannerjee et al. (2008) presented results that appeared to contradict the accepted understanding, offering the possibility that the weathering state of ivory might, after all, offer an indication of age.

In proposing that the changes detected in ivory by FTIR spectroscopy can be used as a means of relative dating, Banerjee et al. (2008) were only comparing material from one type of burial environment, in this case permafrost conditions. Their results do show a direct correlation between these changes and the visible degree of weathering (defined as A: white and unweathered, B: Yellow and slightly weathered and C: brown and extremely weathered), but they present no evidence that the degree of weathering is directly related to increasing age of the ivory. We therefore set out to test the hypothesis that weathering in ivory is correlated with age, using Raman spectroscopy and ivory samples of broadly similar date from a single site. If Bannerjee et al's conclusions are valid, then our samples, standardised for age and location, should be consistent in terms of weathering parameters.

\section{Selection of analytical technique}

FTIR spectroscopy is a relatively destructive technique. To gain a quality spectrum requires either the preparation of a flat surface on the specimen or for a sample of the specimen to be powdered. In addition, FTIR spectroscopy is very sensitive to water content and specimens effectively need to be dehydrated to the same extent to gain good quality spectra for comparison. Sampling of cultural objects is not always curatorially acceptable and even if surface preparation of a discrete area is considered feasible, dehydration of the ivory object would carry a very high risk of catastrophic physical damage. These problems led the authors to consider alternative analytical techniques and Raman spectroscopy was selected as a substitute for FTIR spectroscopy for this experimental work.

Raman spectroscopy has a number of advantages over FTIR spectroscopy. It allows the same changes in microstructure and molecular chemistry to be observed in ivory but good quality spectra are gained without the need for dehydration or surface preparation, beyond brushing off obscuring sediments. Raman spectroscopy also allows comparison to be made over a wider range of wavenumbers, and provides a greater potential to identify the chemical species. Whereas FTIR spectroscopy has a logarithmic dependence between absorption intensity and concentration, Raman spectroscopy has a linear dependence between the concentration of the species under investigation and the irradiance. Although there are several important instrumental geometrical and optical factors that need to be considered for precise quantitative studies this means that if the proportion of a constituent is reduced to $50 \%$ the intensity is also reduced to $50 \%$, all other factors being equal. This allows the changes in specific components in different specimens to be roughly estimated directly from the spectra. 


\section{METHOD}

The Raman spectra were obtained using a Bruker IFS66 with FRA 106 Raman module attachment and $\mathrm{Nd}^{3+} /$ YAG near-infrared excitation at $1064 \mathrm{~mm}$. The spectra were recorded at $4 \mathrm{~cm}^{-1}$ resolution and 2000 scans accumulation. A nominal laser power of $40 \mathrm{~mW}$ was used with a footprint of approximately $100 \mu \mathrm{m}$ at the specimen. This equipment accommodates large sample diversity in terms of size, curvature and irregularity of surface.

\section{Selection of ivory specimens for analysis}

Six mammoth ivory specimens were selected from a waterlogged Pleistocene site, and two permafrost-preserved specimens as comparanda. All the fragments were dry and had been stored at the same ambient RH. Three spectra were collected from each of two surfaces of all the ivory specimens.

The two permafrost-preserved specimens (Figure 1) were off-cuts from the modern commercial ivory carving trade. They are of unknown date and provenance and were included in this study to allow comparison with the FTIR spectra published by Banerjee et al. (2008). The six waterlogged-preserved ivory specimens (Figure 2) were from Lynford Quarry, near Munford in Norfolk UK, excavated in 2002 by the Norfolk Archaeological Unit (Boismier et al., 2003).
Amongst the faunal material recovered from Lynford were the remains of at least 11 mammoths associated with Mousterian stone tools. The mammoths were mostly males and several complete tusks, and 32 plastic sacks of ivory fragments, were recovered. Material from this site was conserved at the University of Bradford, Archaeological Sciences conservation laboratory. A small quantity of the fragmented ivory was retained, untreated, for future research studies: the samples described here were drawn from that material.

The majority of the faunal remains were excavated from the organic rich deposits of a palaeochannel, referred to as Association B (Gamble, in press). The lowermost and uppermost levels of this channel contained sands and gravels deposited by relatively fast flowing water. Between these were the organic silts and sands, bone and ivory, plant and insect remains, which seem to have accumulated at a time when the channel had become a meander, cut off from the main water flow. Optically-stimulated luminescence (OSL) dating of these organic sediments places their deposition at the transition between Marine Isotope Stages (MIS) 4 and 3, approximately 65-57 ka (Gamble, in press).

Some of the mammoth remains had been pushed down through the organic deposits into the underlying sands and gravels, possibly due to bioturbation by other mammoths and megafauna. This had produced substantial variation in the colouration and state of preservation of the bone and
Figure 1: (See colour plate) Two permafrost-preserved mammoth ivory off-cuts of unknown provenance. a, permafrost specimen $b$, permafrost specimen 2 (cut surface) and c, permafrost specimen 2 (weathered surface).

Figure 1: (Voir planche couleur) Deux morceaux d'ivoire de mammouth préservés dans un permafrost d'origine inconnue. a, spécimen de permafrost $b$, spécimen 2 (surface de coupe) et c, spécimen 2 de permafrost (surface d'altération)
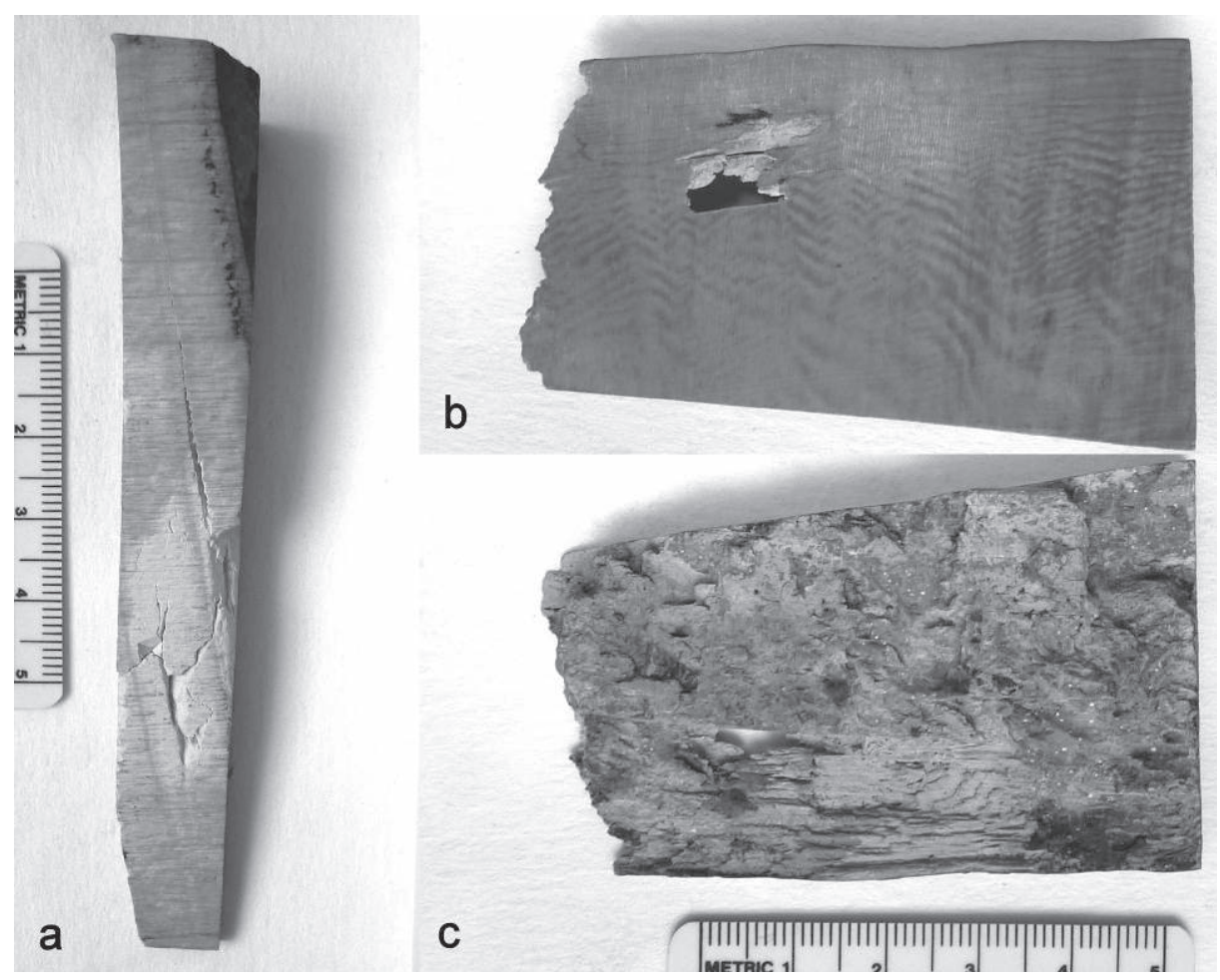


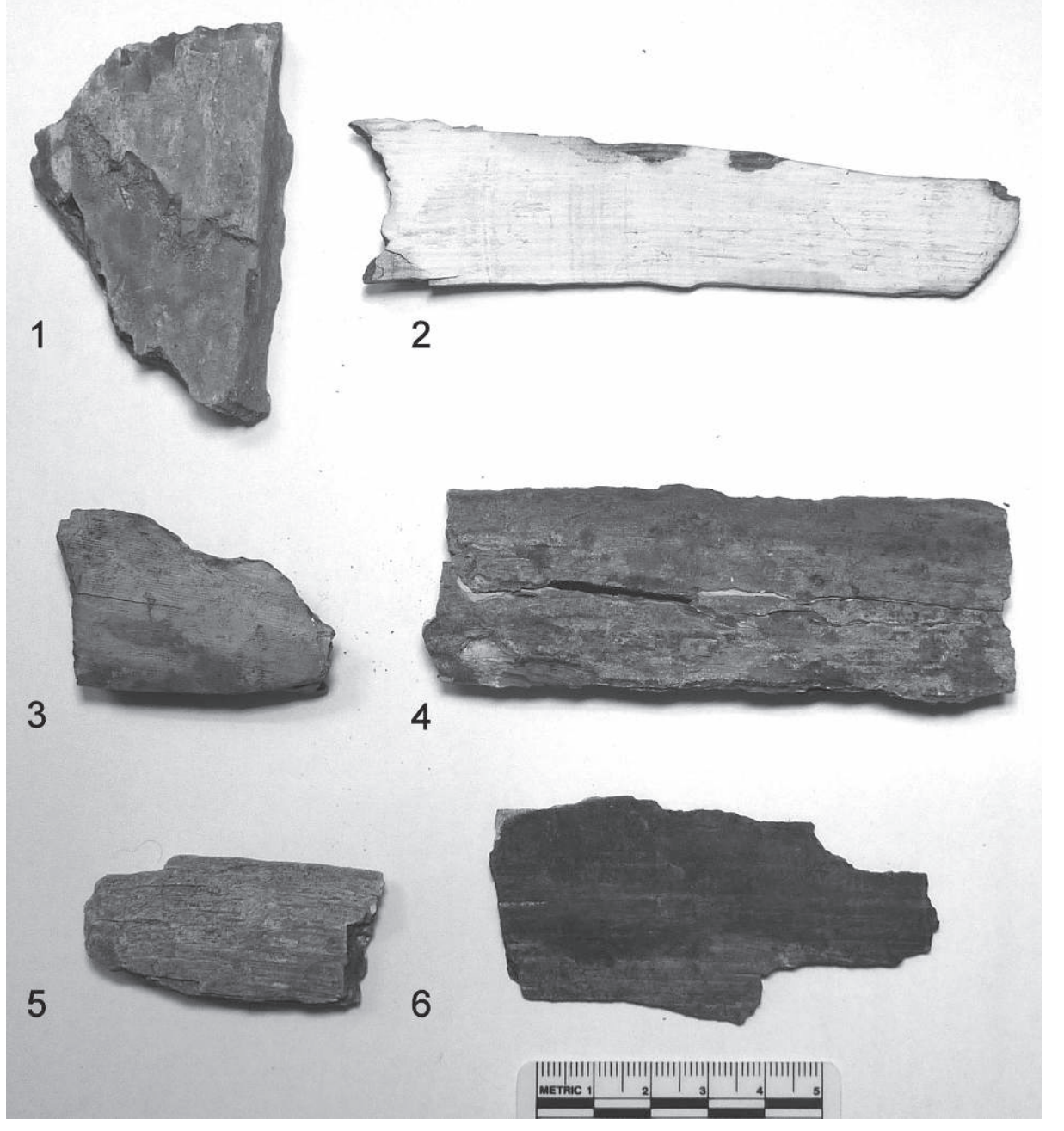

Figure 2: (See colour plate) Six samples of mammoth ivory from waterlogged deposits at Lynford Quarry, Norfolk, UK.

Figure 2: (Voir planche couleur) Six échantillons d'ivoire de mammouth provenant de gisements gorgés d'eau de la Carrière de Lynford, Norfolk, Royaume Uni. ivory material (Figure 2). Generally the bone in the organic deposits was stained dark brown, was relatively robust and had good surface preservation. That in the sands and gravel was greatly fragmented and friable and could be rusty red in colour. One tusk in particular, at the interface between these deposits, showed a range of variation in both colour and condition along its length. The ivory specimens analysed from Lynford were especially selected to represent the full range of preservation in these palaeochannel deposits.

\section{Results}

To aid comparison, all the spectra were normalised on the phosphate 961 band $\mathrm{cm}^{-1}$.

The cut surfaces of the permafrost-preserved ivory provided good quality Raman spectra that captured all the detailed information seen in the FTIR spectra presented by Banergee et al. (2008: Figures 3 and 4). The spectrum of permafrost specimen 2 (Figure 3) showed that both the collagen and the bioapatite were well preserved and looked very similar to spectra of modern elephant ivory (Brody $e t$ al., 2001).

The cut surfaces of permafrost specimens 2 and 1 produced very similar spectra but when the spectrum of specimen 2 is compared with the eroded surface of specimen 1 , there are many differences apparent between them (Figure 4). Although the bioapatite is similarly preserved in both specimens, the collagen is significantly reduced in specimen 1 and in the wavenumber region around wavenumber $1500 \mathrm{~cm}^{-1}$, the peaks show a smearing or broadening, indicating an increase in the characteristic degradation products of collagen. Interestingly the best waterlogged-preserved ivory from Lynford, Lynford 2, has produced a very similar spectrum to permafrost 2 suggesting that the diagenetic changes that have occurred are very similar (Figure 4).

Figure 5 is a stacked plot of four of the Lynford specimens (1 to 4 ) illustrating the range of preservation recorded. 
Figure 3: Raman spectrum of ivory specimen permafrost 2.

Figure 3 : Spectre Raman de spécimen de permafrost 2 .

Figure 4: Stacked plot of Raman spectra of ivory specimens permafrost 1 and 2 and Lyford 2 (white side). Spectra normalised on the phosphate 961 band $\mathrm{cm}^{-1}$

Figure 4 : Spectres Raman des spécimens de permafrost 1 et 2 et de Lynford 2 (côté blanc). Les spectres sont normalisés à la bande du phosphate à $961 \mathrm{~cm}-1$.
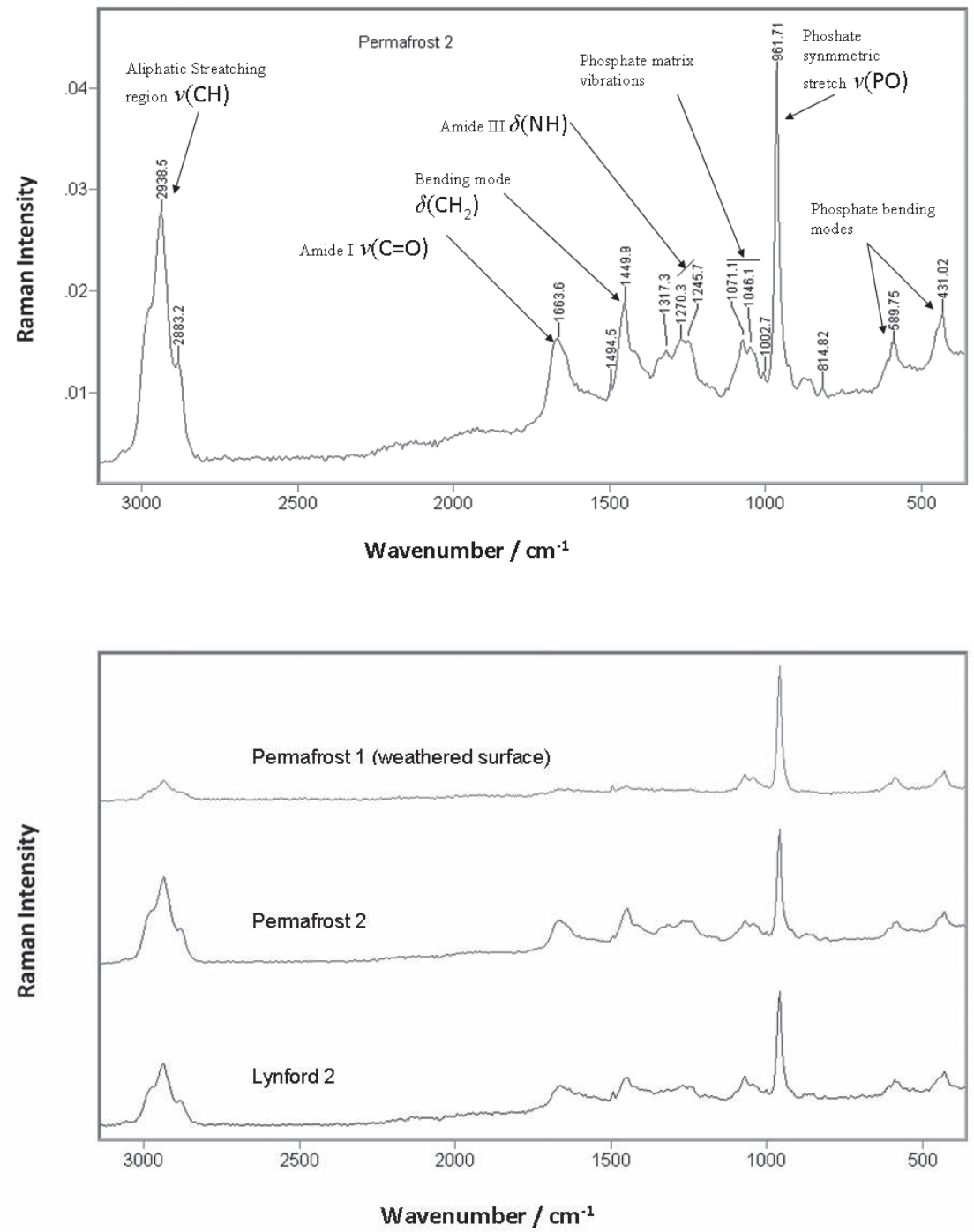

In contrast to Lynford 2, the peak at ca. $3000 \mathrm{~cm}^{-1}$ in the spectrum from Lynford 1 is almost entirely lost and those at $1200-1700 \mathrm{~cm}^{-1}$ are very significantly reduced in intensity, and have spread. In Lynford 3 and 4 the bioapatite is still identifiable but there is little evidence of an organic component and there are very high levels of background emission attributable to absorption of materials from the burial environment. From these spectra alone, it would not be possible to distinguish between the mammoth ivory specimens Lynford 1, 3 and 4.

Both the upper (convex surface) and lower surfaces (concave surface) of Lynford 1 were similar in colour but only the lower surface (Figure 2) showed evidence of contact with the burial sediments. The spectra obtained from the upper and lower surfaces are very much the same, when considering the inorganic matrix, but the residual organic signal from the lower surface is swamped by contamination from the burial environment (Figure 6).

Lynford 2 is a fragment from a larger piece of ivory that has split, following the concentric lamellae of the tusk, as it dried after excavation. The upper surface of the specimen is stained beige by the burial environment but the lower surface, where the split occurred, is white. When comparing these two surfaces the spectra are very different (Figure 7). Despite the increased emission from contamination of the upper surface there is definitely a reduction in the organic component when compared with the lower surface. 


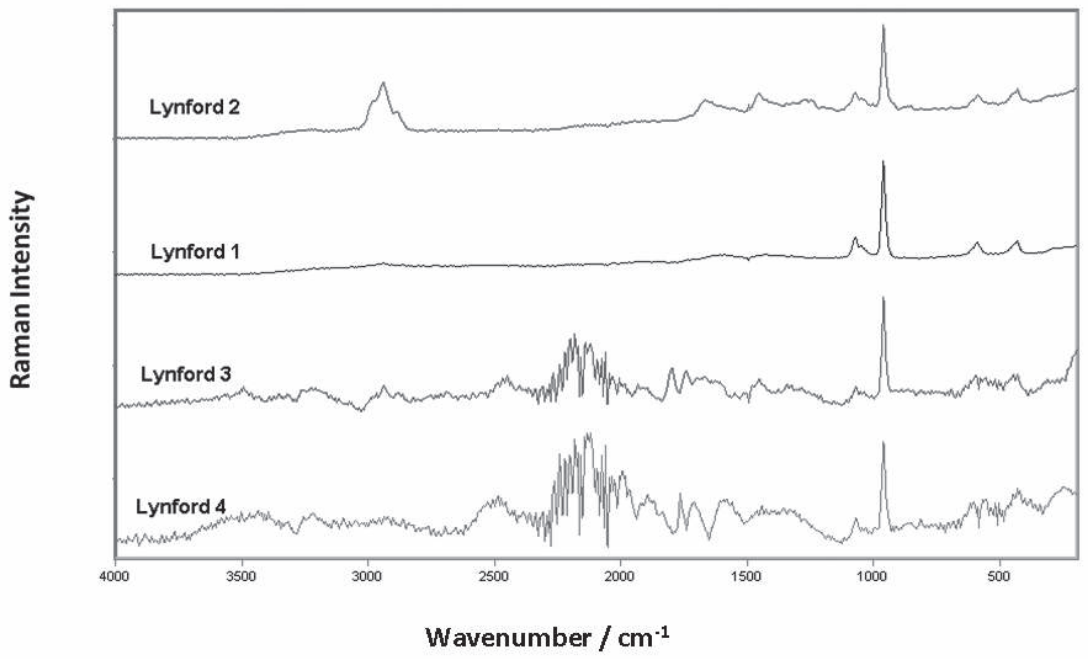

Figure 5: Stacked plot of Raman spectra from Lynford ivory specimens 1 to 4 . Spectra normalised on the phosphate 961 band $\mathrm{cm}^{-1}$.

Figure 5 : Spectres Raman des spécimens d'ivoire 1 et 4 de Lynford. Les spectres sont normalisés à la bande du phosphate à $961 \mathrm{~cm}-1$.

Figure 6: Raman spectra from the upper and lower surfaces of ivory specimen Lyford 1. Spectra normalised on the phosphate 961 band $\mathrm{cm}^{-1}$.

Figure 6: Spectres Raman des surfaces supérieures et inférieures du spécimen d'ivoire de Lynford 1. Les spectres sont normalisés à la bande du phosphate à $961 \mathrm{~cm}-1$.

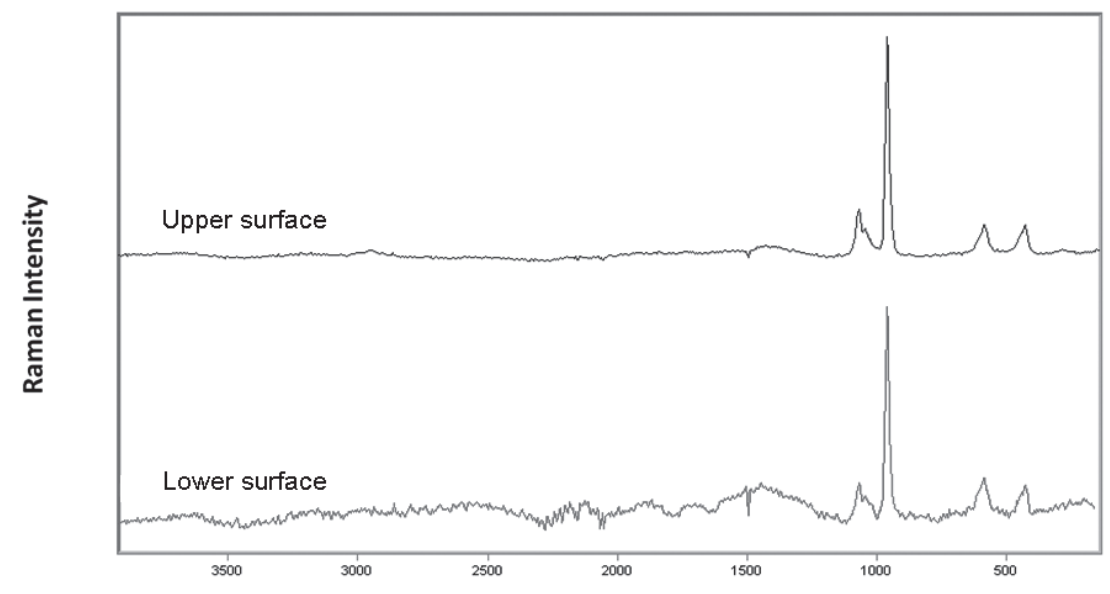

Wavenumber $/ \mathrm{cm}^{-1}$

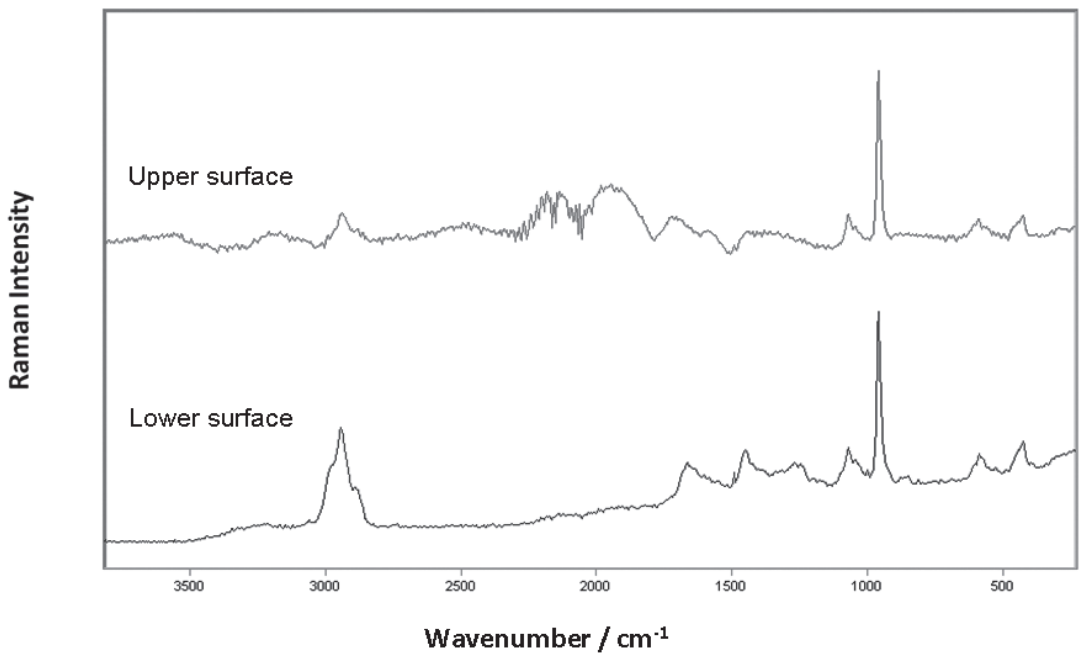

Figure 7: Raman spectra from the upper and lower (white) surfaces of ivory specimen Lyford 2. Spectra normalised on the phosphate 961 band $\mathrm{cm}^{-1}$.

Figure 7 : Spectres Raman des surfaces supérieure et inférieure (blanche) du spécimen d'ivoire de Lynford 2. Les spectres sont normalisés à la bande du phosphate à $961 \mathrm{~cm}-1$. 


\section{DisCuSSION}

Raman spectroscopy has provided information on the chemical composition of the ivories comparable with that obtained by FTIR spectroscopy. Contamination of surfaces exposed to the burial sediments could have been reduced by sample preparation, as is done for FTIR spectroscopy, but even then it cannot be suggested that the results obtained could have been used in dating with any greater confidence.

Analysis of the cut surfaces of the two permafrost samples indicated that both are well preserved ivory but as the origins of these off-cuts are not known it cannot be discounted that they are of very different date. The similarities in the results only indicate that they are probably of the same commercial grade of ivory. However if the assumption that the state of preservation of the ivory and its age are directly linked is valid, the weathered areas of sample 1 would have to be very much older than the ivory exposed on its cut surfaces. Sampling deep within the core of cultural objects, to avoid the more weathered exterior, could be very problematic.

The Lynford ivory provided an opportunity to compare the analytical results of ivories of relatively contemporaneous date, preserved in a waterlogged environment from a single context, but with marked variations in the surrounding sediments. The wide variability in the preservation of the organic and inorganic components of the ivory clearly show that many factors, other than the time elapsed from the death of the mammoth, contributed to the state of preservation of the ivory. Any assessment of age based on the Lynford samples would conclude that they represent material of a wide range of age, which would, of course, be quite misleading.

\section{Conclusion}

For the state of preservation of ivory to be useful as an indicator of the age of the ivory the observed diagenetic changes have to have happened in a consistent and predicable manner. This study confirms that the preservation of ivory from a single site and even across the surface of a single object may vary too much to allow even an approximate relative chronology to be obtained. Results published previously, that appear to show the contrary, would appear to be the product of small sample numbers and coincidental correlation for which there was no true cause and effect relationship. FTIR and Raman spectroscopy can detect and quantify changes that occur in ivory as it weathers but these changes cannot be used as an indication of the relative age of ivories.

\section{Acknowledgements}

To Bill Boismier, Clive Gamble and Nigel Larkin, for specimens and information relating to the Lynford Quarry excavations, Terry O'Connor for the permafrost ivory specimens and Alan Ogden for the translation of the abstract. Sonia O'Connor's post-doctoral fellowship, 'Cultural Objects Worked in Skeletal Hart Tissues', is funded by the AHRC/EPSRC Science and Heritage Programme. We also thank the University of Bradford for their support in this project.

\section{References}

Banerjee, A., Bortolaso, G., Hofmeister, W. PetrovićPrelević, I., KIEWISCH, B., 2008 - Investigation of Quality of Commercial Mammoth Ivory by means of X-Ray Powder Diffraction (Rietveld Method) and FTIR Spectroscopy. In G. Bortolaso, (ed.). Ivory and Species Conservation: Proceedings of INCENTIVS Meetings (2004-2007). Bundesamt Für Naturschutz, Bonn, 51-63.

Boismier, W. A., Schreve, D. C., White, M. J., Robertson, D. A., Stuart, A.J., Etienne, S., Andrews, J., Coope, G. R., Field, M. H., Green, F. M. L., Keen, D. H., Lewis, S. G., French, C., Rhodes, E., Schwenninger, J.-L., Tovey, K., Donahue, R.E., Richards, M. P., O'Connor, S., 2003 - A Middle Palaeolithic site at Lynford Quarry, Mundford, Norfolk: Interim statement. Proceedings of the Prehistoric Society, 69: 315-324.

Brody, R. H., Edwards, H. G. M., Pollard, A. M., 2001 Chemometric methods applied to the differentiation of Fourier-transform Raman spectra of ivories. Analytica Chimica Acta, 427: 223-232.

Edwards, H. G. M., Jorge Villar, S. E., Nik Hassan, N. F., Arya, N., O'Connor, S., Charlton, D., 2005 - Ancient biodeterioration: an FT-Raman spectroscopic study of mammoth and elephant ivory. Analytical and Bioanalytical Chemistry, 383: 713-720.

Edwards, H. G. M., Brody, R. H., Nik Hassan, N. F., Farwell, D. W., O'Connor, S., 2006 - Identification of archaeological ivories using FT Raman spectroscopy. Analytica Chimica Acta, 559: 64-72.

GAMBLE C., (in press) - Neanderthals amongst Mammoths: Excavations at Lynford Quarry, Norfolk. English Heritage, London.

Smith, C. I., Nielsen-Marsh, C. M., Jans, M. M. E., Collins. M. J., 2007 - Bone diagenesis in the European Holocene I: patterns and mechanisms. Journal of Archaeological Science, 34: 1485-1493.

Nielsen-Marsh, C. M., Smith, C. I., Jans, M. M. E., Nord, A., Kars, H., Collins, M. J., 2007 - Bone diagenesis in the European Holocene II: taphonomic and environmental considerations. Journal of Archaeological Science, 34: 1523-1531. 